e-ISSN: $2536-4596$

KARE- Uluslararası Karşıllaştırmalı Edebiyat, Tarih ve Düşünce Dergisi

KARE- International Comparative Journal of Literature, History and Philosophy

Başlık/ Title: A Feminist Reading of Limon and Zeytin: Motherhood and Gender Roles

Yazar/ Author

Betül Ateşci Koçak

Damla Katlan

\section{ORCID ID}

0000-0002-7937-953X

0000-0003-4436-6621

Makale Türü / Type of Article: Araştırma Makalesi / Research Article Yayın Geliş Tarihi / Submission Date: 4 Aralık / December 2021

Yayına Kabul Tarihi / Acceptance Date: 29 Aralık / December 2021

Yayın Tarihi / Date Published: 31 Aralık / December 2021

Web Sitesi: $\underline{\text { https://karedergi.erciyes.edu.tr/ }}$

Makale göndermek için / Submit an Article: http://dergipark.gov.tr/kare 


\section{Uluslararası İndeksler/International Indexes}

\section{INDEX $\circledast$ COPERNICUS ता}

$\begin{array}{llllllllllllll}\text { I } & \text { N } & \text { T } & \text { E } & \text { R } & \text { N } & \text { A } & \text { T } & \text { I } & \text { O } & \text { N } & \text { A } & \text { L } & \text { DRJI }\end{array}$
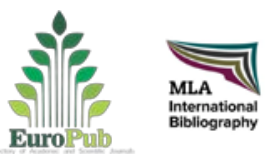

Index Copernicus: Indexed in the ICI Journal Master List 2018 Kabul Tarihi /Acceptance Date: 11 Dec 2019

MLA International Bibliography: Kabul Tarihi /Acceptance Date : 28 Oct 2019

DRJI Directory of Research Journals Indexing: Kabul Tarihi /Acceptance Date: 14 Oct 2019

EuroPub Database: Kabul Tarihi /Acceptance Date: 26 Nov 2019

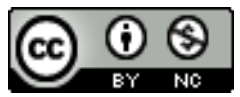

This work is licensed under a Creative Commons AttributionNonCommercial 4.0 International License. 
Yazar: Betül Ateşci Koçak, Damla Katlan*

LIMON VE ZEYTINN'İN FEMINISTT BİR OKUMASI: ANNELİK VE CINSIIYET ROLLERİ

Özet: Annelik ve toplumsal cinsiyet rollerinin analizi, feminist teorinin en önemli ilgi alanlarından biri olmuştur. Tarih boyunca toplumsal cinsiyet rollerinin geleneksel anlayışı, toplumda ezilen kadınların ortaya çıkmasına sebep olmuştur. Toplumsal cinsiyet rollerine ilişkin geleneksel algının yansımaları, ebeveynlerin evliliklerdeki rollerine yansımış ve çoğunlukla erkeği kadından üstün gören içselleştirilmiş rollerden dolayı iş bölümünde eşitsizliğe neden olmuştur. Kadınlardan ev hanımı olarak tüm ev işlerini ve çocuk bakımını üstlenmesi beklentisi, erkeklerin ev işlerinden ve buna dahil olan çocuk bakımından muaf tutulması yönündeki düşünceler ve uygulamalar çok sayıda evliliği etkilemiş ve bahsedilen doğrultuda yönlendirmiştir. Kadın ve sonrasında anne, öngörülen hali deneyimledikçe, evliliklerde iş bölümü olasılığından bahsetmek oldukça zorlaşır çünkü geleneksel evlilikler, çocuk bakımından ve ev işlerinden yalnızca veya ağırlıklı olarak annelerin sorumlu olduğu ve babaların sorumluluğun hiç ya da azami olması gerektiği şeklindeki yerleşik anlayışı desteklemektedir. Türk karikatürist Salih Memecan'ın çizgi romanları Annem, İste Benim Annem ve Sihirli Annem, evliliklerde ev işlerinin bölünmesine ilişkin sorunlara örnek teşkil eden çizgi romanlar arasında yer alıyor. Aile ortamında toplumsal cinsiyet rollerine ilişkin oldukça köklü bir algının örneğini çizen yazar, eşi Çıtçıt'ın (Mayıs) adının ve yerinin oldukça hiçe indirgendiği bir evlilikle karşımıza çıkar. Bu makalenin amacı, İkinci Dalga feminizmin fikirlerinden hareketle Salih Memecan'ın Annem, İşte Benim Annem ve Sihirli Annem adlı çizgi romanlarını feminist teori ışığında incelemektir. Çıtçıt (Mayıs) ve Babişko (Bubs) ataerkil toplumlardaki cinsiyet rolleri çerçevesinde ebeveyn ve çift olarak incelenecektir.

Anahtar Kelimeler: Annelik, Toplumsal Cinsiyet Rolleri, İşbölümü, İkinci Dalga Feminizm, Çizgiroman.

\section{A FEMINIST READING OF LIMON AND ZEYTIN: MOTHERHOOD AND GENDER ROLES}

Abstract: The analysis of motherhood and gender roles has been one of the most crucial concerns for feminist theory. Throughout history, the conventional understanding of gender roles has resulted in the oppressed women in society. There are also the repercussions in parents' roles in marriages mostly resulting in inequality in the division of labour due to the internalized roles that see men superior to women. This belief has affected and directed numerous marriages as a false model where the woman is loaded with all the domestic work as a housewife and man is the sole breadwinner who is exempted from domestic work and has loose connections also with childcare, which is also included in domestic affairs. As the wife and thus mother becomes the projected figure, it becomes quite hard to mention the possibility of the division of labour in marriages because conventional marriages favour the established understanding that only or predominantly mothers are responsible for childcare and housework and that fathers should be distanced from this process. Turkish cartoonist Salih Memecan's comic books Annem, İşte Benim Annem and Sihirli Annem are among the comics portraying examples of the problems about the division of domestic work in marriages. Drawing an example of a rather long-established perception of gender roles within a family sphere, the author comes up with a marriage where the name and place of the wife figure, Çıtçıt (May) is quite diminished. Taking its departure from the ideas of the second-wave feminism, the purpose of this paper is to study Salih Memecan's

\footnotetext{
* Dr Öğr Üyesi., Erciyes Üniversitesi, Edebiyat Fakültesi, İngiliz Dili ve Edebiyatı Bölümü, batescikocak@erciyes.edu.tr, ORCID: 0000-0002-7937-953x

Doktora Öğrencisi., Erciyes Üniversitesi, Sosyal Bilimler Enstitüsü, İngiliz Dili ve Edebiyatı, damlakatlan@trabzon.edu.tr, ORCID: 0000-0003-4436-6621
} 
comic books Annem, İşte Benim Annem and Sihirli Annem in the light of feminist theory. Çıtçıt (May) and Babişko (Bubs) will be analyzed shedding light on their duties as parents and as a couple with regards to gender roles.

Keywords: Motherhood, Gender Roles, Division Of Labour, Second-Wave Feminism, Comics.

\section{Introduction}

Salih Memecan, best known for creating Limon and Zeytin (Lemon and Olive) belonging to the "Sizinkiler" comic series, is a Turkish cartoonist, who publishes his daily "Bizimcity" caricatures in a daily newspaper and weekly ones on the magazine Aktüel. Memecan, who composed more than one hundred comic books, published his first comic book under the title Limon and Zeytin - Ay Pardon! which dates back to the year 2001. In 2014, based on the adventures from Memecan's comic book, Limon and Zeytin was adapted into an animation for kids and featured on Disney Junior Channel as Limon and Oli across the world. In the comic book series of Sizinkiler, the reader catches the opportunity to become acquainted with the traditional Turkish family atmosphere with the figures portrayed as chickens. Through the family members, Memecan reflects the soul of a traditional middle-class Turkish family where the mother is the one who most cares for the house as the father goes to work and spends his time for more intellectual things.

İşte Benim Annem, which is among his comic book series Limon and Zeytin, was released in 2015. The chicken mother character Çıtçit is represented as a self-sacrificing mother figure to bring up a child with all the responsibilities only on her shoulders beside loads of housework. Depicting mother-daughter and wife-husband relationships, the author, in fact, comes up with a mother figure trapped in a world where she is expected to perform mostly within the limits of the house.

Published in 2016, Sihirli Annem portrays Çıtçıt as a woman who puts an undeniable effort to be a perfect mother embracing a powerful maternal instinct and demonstrating strong detachment to her family. Throughout the story, the reader often witnesses Çıtçıt's never-ending struggle to catch up with the chores and duties towards her daughter and husband. In the following year after the publication of Sihirli Annem, Memecan's other comic book Annem, Limon and Zeytin series was specifically attributed to mothers and released on Mother's Day. In this story, Çıtçıt's overexertion to deal with the household chores prevails. Instead of celebrating Mothers' Day, Çıtçıt continues to deal with the house chores without even realizing or thinking about sparing time for herself. 
Putting these three comic books İşte Benim Annem, Sihirli Annem and Annem under the scope, this paper initially purposes to analyse the mother figure Çıtçıt with a feminist approach, which rejects the constricting ties of motherhood and wifehood. The paper will also focus on the misunderstanding of the married women's role via the mentioned comic books revealing how the life of the mother figure is limited to house and housework as opposed to the understanding of feminist thought.

Memecan's comics, especially the ones mentioned above, take the readers' attention with the often-seen mother figure Çitçıt compared to her husband Babişko. She appears in every part of the house as she passes most of her time indoors doing several kinds of housework almost without giving a break during the day. At first glance, the reader may consider Çıtçıt as an amazing mother figure doing her best to be an impeccable mother and wife. However, as the sole responsible for domestic stuff, she cannot claim any pleasures for herself. Though she consumes coffee during the day, it is to get more energy to do more work instead of relaxing or having a break. She is always seen in a rush with a busy mind to catch up with the endless list of work at home. There are hardly any scenes she is resting or reading as opposed to her husband, named Babişko.

The father figure, Babişko, is represented as a character who most of the time appears sitting in the living room with his newspaper and magazine. $\mathrm{He}$ is the sole breadwinner in the house and depends on this as an excuse for not doing any housework. He does not seem to care about household chores and take responsibility for his daughter, Limon either. Although he appears to be a kind father fond of his daughter, he does not actively take part in the process of bringing her up when it comes to taking responsibility. He is quite the contrary of the mother as the mother's world is filled with several details about the housework from cleaning, cooking to childcare. With a purpose to break these taboos established by the male-centric way of thinking, the feminist perspective proposes a way to hold a more egalitarian family environment supporting the idea that there should not be a matter of imbalance between parents with regards to childcare and household chores.

Before focusing on the feminist reading, it is also important to highlight the meaning of the parents' names. In Turkish, Çıtçıt means snap fastener and Babişko means daddy and/or papi. Babişko does not eliminate the meaning of father, yet the word beholds more sympathy and love towards the father. When there is a "babişko" figure in the house, there is almost no authority of the father, no argument with the children as the "babişko" is quite away from taking any responsibility or task with the childcare and thus, stays away from 
the problems and difficulties of raising a child and therefore always remains as the most preferred and favourite figure for the child/ren. On the other hand, giving the mother character nothing but an irrelevant and meaningless name like Çıtçıt gives us hints about the loose presence of the mother figure as a woman. As the word holds the sound of the snap fastener, in a cultural sense, it can also refer to Çıtçıt's continual yet in vain talking in the house. Briefly, the huge difference in names in terms of the meaning in this comics series is quite related to the flow and roles of the characters. By trivializing the status and the character with a rather irrelevant and absurd name for the mother and giving a somewhat charismatic and admirable name for the father, the author lays out a family structure that does not take a step forward to draw out a family reduced from the traditional understanding of gender roles.

\section{Feminist Background of Motherhood and Gender Roles}

The meaning of woman has been a matter of several controversies since ancient times. They have been long defined as a mother, daughter, wife, nanny, servant, caretaker, and housewife. Such labelling of women has its certain effects dating back to the essentialist thinking that see women as inferior to men mostly in terms of intelligence that's why they are attained with roles that require less education and strength, which is also an unfair and false belief. And less public involvement of women in such duties makes them more suitable for women according to the essentialist thinking. Also, the rooted idea that women are closer to nature and thus they are the protecting and nurturer ones have affected the roles attained to women. For centuries, women who do not marry, give birth, breastfeed, cherish reproducing yet show intellectual tendencies such as reading, receiving higher education, showing interest in arts have long been humiliated, ignored, and thought of as short. As such thoughts shaped the society through the dominant patriarchal discourse for centuries, marriages have been affected and shaped according to them. Today, there are still similar ill-thoughts either in marriages or between couples deriving from the idea that a woman belongs to the home sphere no matter she works or not.

First-wave feminism (19 $9^{\text {th }}$ century) had to strive for the rights of women in terms of higher education, right to vote, claim property holding and custody whereas the second-wave feminism, beginning in the early 1960s, cried out the necessity of anti-essentialism and thus defended urgent recovery in a wider range of issues such as sexuality, family, division of labour, workplace, reproductive rights, official legal inequalities, domestic violence, marital rape, changes in custody as well as divorce rights. Though there are several cases 
regarding the struggle for juridical rights of women, the problems regarding domestic work and childcare between couples are among the most frequent problems in marriages, which needs an insight into the relationship between gender roles and motherhood.

The relationship between feminism and motherhood has a complex background because there exist numerous feminist approaches ranging from the radical, which rejects motherhood supporting that it leads up to the oppression of women, to the mild one which romanticizes motherhood rather than regarding it as a victimization or oppression of women. ${ }^{1}$ One of the radical views put forward by Jeffner Allen, which strictly rejects motherhood, is based on the idea that motherhood has a strong relation to "a history in which women remain powerless by reproducing the world of men" and women have no other choice but becoming mothers and that they are unable to be free in this male-dominated society. ${ }^{2}$ In other words, she sees motherhood as a kind of threat for women because the reproduction of women-only serves for the male sovereignty and states that it's harmful to them both biologically and psychologically. To set an example of a negative psychological impact on women, it may end up with a kind of depression called post-partum because of experiencing some inner struggles relevant to motherhood. Bell Hooks, a widely-known name of second-wave feminism, takes attention and criticizes "the nineteenth century men and women who extolled the virtues of cult of domesticity." ${ }^{3}$ Such belief resulted in almost refusal of motherhood by some feminists as they considered parenting and thus motherhood as a task accomplished to find "affirmation and appreciation" in society as it "draws heavily on sexist stereotypes" embellished with romanticization and resulted in the division and alienation of the masses of women from the feminist movement. ${ }^{4}$

Rich evolutionized the idea about motherhood as she "made a distinction between motherhood as a patriarchal institution and mothering as a woman's potential relationship to her powers of reproduction and children." 5 This sharp distinction between "motherhood" as "the patriarchal institution" and

\footnotetext{
1 Tatjana Takševa, "Mother Love, Maternal Ambivalence, and the Possibility of Empowered Mothering," Hypatia 32, no. 1 (2017): 177, https://doi.org/10.1111/hypa.12310.

2 Jeffner Allen, "Motherhood: The Annihilation of Women," in Mothering: Essays in Feminist Theory, ed. Joyce Trebilcot (Totowa, N.J. : Rowman \& Allanheld, 1984), 316.

${ }^{3}$ Bell Hooks, Feminist Theory: From Margin to Center (Boston: South End Press, 2000), 135.

${ }^{4}$ Ibid.

${ }^{5}$ Thompson, Mary, "Third Wave Feminism and the Politics of Motherhood," Genders 1, no. 2 (2016), $\quad$ https://www.colorado.edu/genders/2017/03/17/third-wave-feminism-and-politicsmotherhood.
} 
"experience of mothering" covers a woman's maternal experience specific to her and has nothing to do with being oppressive for women. ${ }^{6}$ In terms of the patriarchic sense, she claims, "most women have felt their own power in the patriarchal sense- authority over or control of another." 7 In that sense, motherhood turns into a potential of power for women in terms of gaining empowerment by virtue of the fact that women may take the opportunity to decide for their lives instead of fulfilling the "climate of expectations." 8

For many feminists, there is a close relationship between motherhood and nature while some of them refuse this idea that motherhood is something innate to women. The reason why some feminists reject this innateness assumption is that when it is accepted that motherhood is natural to women, placing the whole responsibility of childcare on mothers is legitimized or appeared to be a "natural responsibility" for them. ${ }^{9}$ The idea that motherhood is an indispensable virtue for all women does not only eliminate the identity of women but also sets a domain on women disregarding their existence and body, also hindering for her the impossibility of physiological and psychological fluctuation during childcare. As the effort with the domestic affairs is generally deemed worthless and trivial, the workforce spent indoors is taken for granted and the same vicious things are expected from the same person, which is generally woman and/or mother, regardless of the suffocating sense it gives.

As an alternative solution to the heaviness of unshared domestic work between couples, Andrea O'Reilly touches on the term named "empowered mothering" which suggests mothers get help from others in raising child instead of "regarding childcare as the sole responsibility of the biological mother" opposing to "24/7-mothering as necessary for children." Empowered mothers, unlike the ones who practice patriarchal motherhood, have the power to turn to "friends, family, and their partners to assist with childcare" and this community may be termed as "co-mothers" or "other mothers." She asserts such kind mothers mistakenly believe that good mothering entails "excessive time, money and energy." As a consequence of ignoring their own needs and putting their children's needs in the first place, they become

\footnotetext{
6 Takševa, "Mother Love, Maternal Ambivalence and the Possibility of Empowered Mothering," 182.

${ }^{7}$ Adrienne Rich, Of Woman Born (New York: Norton Publishing, 1986), 67.

${ }^{8}$ Joanna Russ, How to Suppress Women's Writing (Austin, Texas: University of Texas Press, 1983), 10.

9 Gerda Neyer and Laura Bernardi, "Feminist Perspectives on Motherhood and Reproduction," Historical Social Research / Historische Sozialforschung 36, no. 2 (136) (2011): 165-66.
} 
incapable of fulfilling their "selfhood" or defining and realizing their needs as an individual, and have difficulty in expressing themselves in many areas such as "work, activism, friendships, relationships, hobbies, and motherhood." 10 Therefore, she suggests a world where the mother does not feel entrapped and that the child is not a burden. She explains that motherhood should not be understood as one's alienation from social life and that society's loading too much meaning on motherhood is nothing more than a burden for women.

Included in domestic affairs, childcare is another task that can create problems in marriages on account of gender inequality. With the rooted expectation that women belong to the domestic sphere, that they are innate mothers and mother is the nurturer and thus the main carer of the child in addition to the glorification of manhood as the holder of analytic intelligence, load another heavy task on mothers. There are several tasks expected only from women regarding childcare such as breastfeeding, nurturing, keeping the child clean and helping with the school stuff in the following years.

Adrianne Rich lays stress on the necessity of breaking down the conventional understanding of gender roles in childcare and work- patterns enlightening that there should be an equal share of motherhood and fatherhood in the process of caring and nurturing. As a consequence of this equal share of parental labour, women would eventually stop being grateful to fathers when they take even a trivial responsibility towards their own children and women would not be regarded as "special" since they fulfil their maternal responsibilities. Another vital point that she emphasizes is even if fathers take a partial share in childcare and nurturing, women cannot distance themselves from being a leading figure in these issues. ${ }^{11}$ In other words, women have internalized these domestic roles so deeply that they won't be able to share them on an equal basis, on the contrary, they will volunteer to take almost the whole responsibility because of the heavy burden of the internalized gender roles since childhood.

Simone de Beauvoir explicitly underlines the circumstances of women under which they have to perpetuate their lives and how their characters are both traditionally and improperly depicted in a predominantly male society. Within the sphere of patriarchy, the woman is "earthy, commonplace, basely utilitarian" whose existence revolves around "cooking and washing diapers" and whose duty consists of nothing more than a "monotonous repetition of

\footnotetext{
10 Andrea O'Reilly, Matricentric Feminism: Theory, Activism, and Practice (Bradford, Ontario: Demeter Press, 2016), 142.

${ }^{11}$ Rich, Of Woman Born, 216.
} 
life" which seems quite "natural" for her "to repeat, to begin again without ever inventing, for time to see her go round and round without ever leading anywhere". ${ }^{12}$ Their body is "shut up in a kitchen or in a boudoir" in a situation where their soul is "consecrated entirely to her own family" without the possibility of having a sort of social communication with others. ${ }^{13}$ The feminist theory stands against this degrading situation of women- especially mothers- propounding that women may freely have part actively in social life, realize their potential, spare some time for pleasure or self-care, involved in various activities - that is to say, they should have the power to open the doors of the outer world but not be trapped in their houses or kitchens striving for household chores. Some figures written on woman, motherhood and gender including Simone de Beauvoir, Betty Friedan, Shulamith Firestone, Jeffner Allen and Patrice DiQuinzo indicate that it would be for the benefit of women to approach motherhood with "a social constructivist perspective" which provides them to "engage in other activities as well as mothering." 14

Regarding cultural background and differences in family structures, even though the position of women in society, experience of motherhood and gender roles in marriages are not universal, it is still possible to detect some similarities in the status of women, mothering and roles among cultures. In Turkish culture and these comics, women are represented as the characters whose rank in social scale are inferior compared to that of men. Leading a life within the boundaries of their houses, mothers are the leading figures in chores and childcare while father figures generally stand behind this process but lead as the breadwinner.

Just as Beauvoir sets forth, women are considered as God-like beings by society when they become mothers ${ }^{15}$, Ayşe Bilge Selçuk points to the fact that motherhood is regarded as a sacred attribute and this sacredness becomes oppressive for women since the idea that their only duty is mothering is imposed to them and every single second that they spare for anything else turns into a sense of guilt. ${ }^{16}$ The reason is simply because of the expectations of society from women to practice domestic as if it was their responsibility. Accordingly, in a situation incarcerated in this idea, the notion of motherhood evokes similar pictures in almost every culture: "patience, self-sacrifice,

\footnotetext{
${ }^{12}$ Simone De Baeuvoir, The Second Sex (London: Jonathan Cape, 1953), 573.

${ }^{13}$ Ibid., 574.

${ }^{14}$ Patrice Diquinzio, "Exclusion and Essentialism in Feminist Theory: The Problem of Mothering," Hypatia 8, no. 3 (1993): 5.

${ }^{15}$ Beauvoir, The Second Sex, 578.

${ }^{16}$ Ayşe Bilge Selçuk, “Türkiye' de Ebeveynlik,” Cogito 81 (2015), 115.
} 
compassion, charity and unconditional love towards children."17 Gündüz points to the fact that it proceeds in the same way in Turkey and through the feminist movement, women raise their voice and struggle to draw their path "respected as individuals, not only as mothers, wives or sisters." 18 Although there is growing awareness about the rights of women thanks to the feminist thought and movement, there still exists rhetoric that ignores the rights of women as individuals just like in the comics series analyzed in this paper.

\section{A Feminist Reading of Limon and Zeytin: Motherhood and Gender Roles}

In this section of the study, how motherhood is reflected through the comic strips of Salih Memecan Annem, İste Benim Annem and Sihirli Annem is elucidated in addition to the position of the mother and father figure within this traditional marriage structure with a highlight on the division of labour throughout the gender perspective.

Çıtçıt is represented as an excellent mother figure who always makes an incredible effort to carry out the responsibilities towards her family, especially her daughter Limon. She fussily deals with each matter related to her daughter, even including her eating habit. She tenderly seeks several ways to make her daughter eat since Limon is not much into eating. The reader quite often comes across with the conversations between Çıtçıt and Limon which display the mother's constant effort to make her eat properly. When Limon does not respond to her mother's call for mealtime, Çıtçıt repeats the call with a paper on the TV screen while Limon is watching. And there are also times when Limon asks for a bribe on the condition that she eats something.

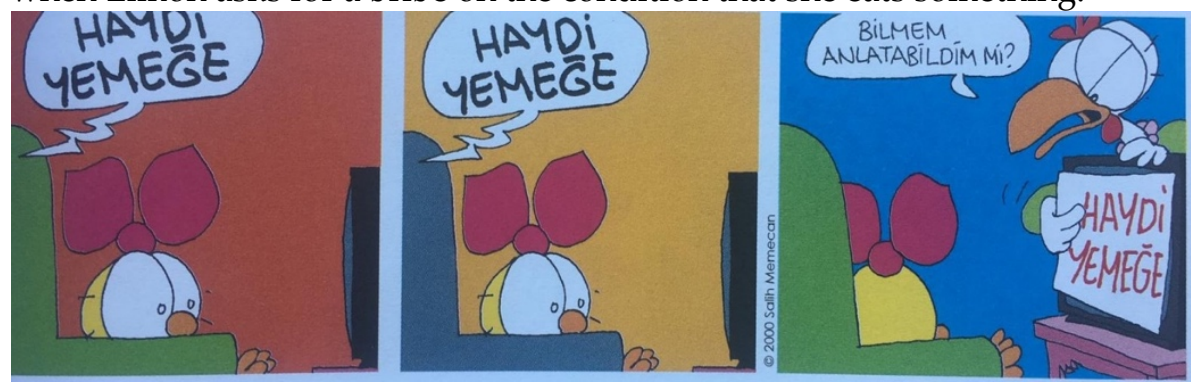

\footnotetext{
17 Senem Üstün Kaya, “Angels or Demons: A Comparative Analysis of Motherhood Concept in World Literature," Akademik Dil ve Edebiyat Dergisi 4, no. 4 (30 December 2020): 874, https://doi.org/10.34083/akaded.755543.

18 Zuhal Yeşilyurt Gündüz, “The Women's Movement in Turkey: From Tanzimat towards European Union Membership 1," Perceptions: Journal of International Affairs 9, no. 3 (1 September 2004): 122.
} 
Fig. 1: Time to eat (Sihirli Annem, 23).

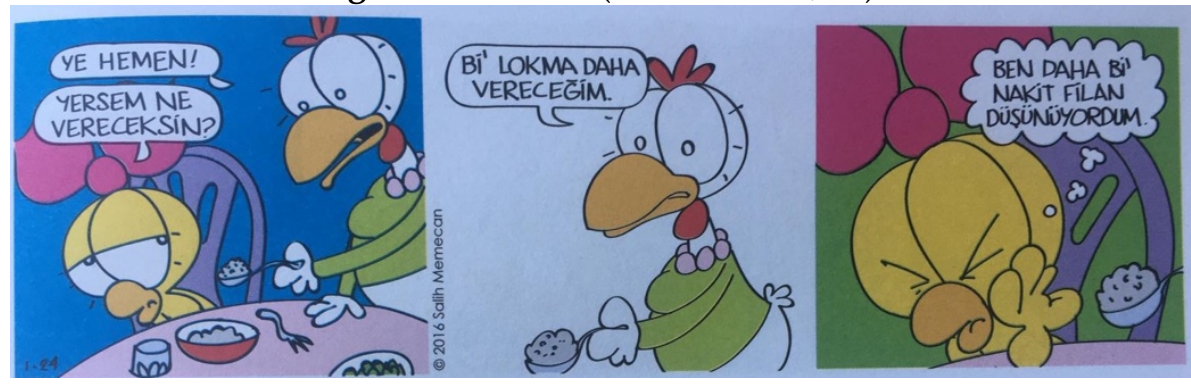

Fig. 2: Limon's struggle against eating (Annem, 39).

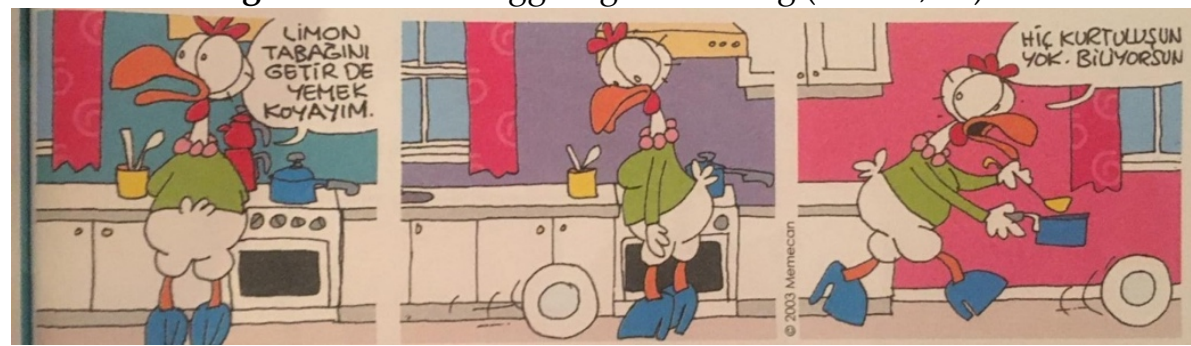

Fig. 3: Çıtçıt's insisting on feeding Limon (İşte Benim Annem, 34).

Another matter which Çıtçıt concerns about is Limon's education and school life. She is considerably interested in Limon's school life and tries to help her while studying. She sometimes exaggerates and makes sure whether everything about school is fulfilled. Being a mother showing extremely caring attitudes, she doesn't allow her daughter to take her own responsibility. Echoing Rich, Çıtçıt uses the empowerment that she has gained through her motherhood identity and starts taking decisions upon their lives as well as making choices on behalf of family members but herself. In the comic series, it is possible to see many panels that Çıtçıt worries about Limon's homework and behaves like a teacher towards her daughter. On the other hand, Babişko stays indifferent to such cases as he does the same with Limon's eating habits. There is not even one panel in which the reader could see the father and the daughter studying together. It becomes pretty noticeable to figure out the acute distinction between the mother and father's manners about this education issue if one thoroughly scans the panels. As an example, in one of the panels in Sihirli Annem and İște Benim Annem, Çıtçit puts pressure on Limon to finish her homework and to go to school while in another one, she helps her with Limon's homework: 


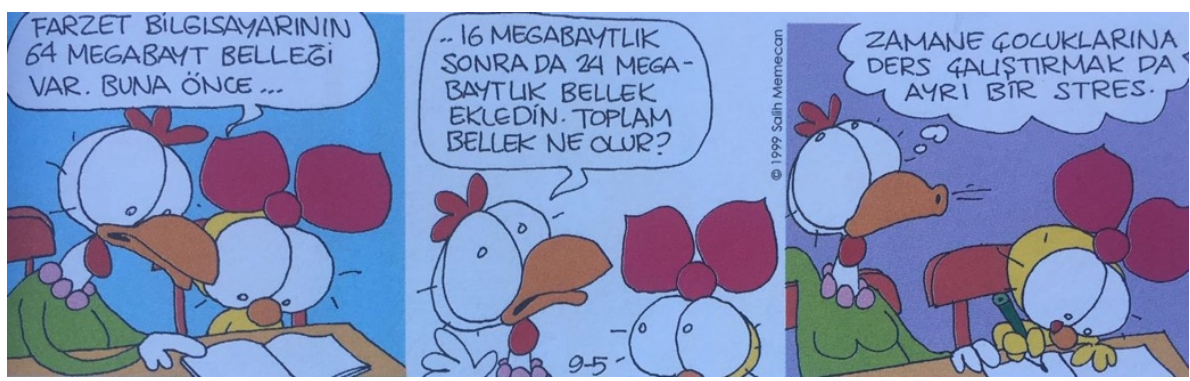

Fig. 4: Çıtçıt studying together with Limon (Sihirli Annem, 19).

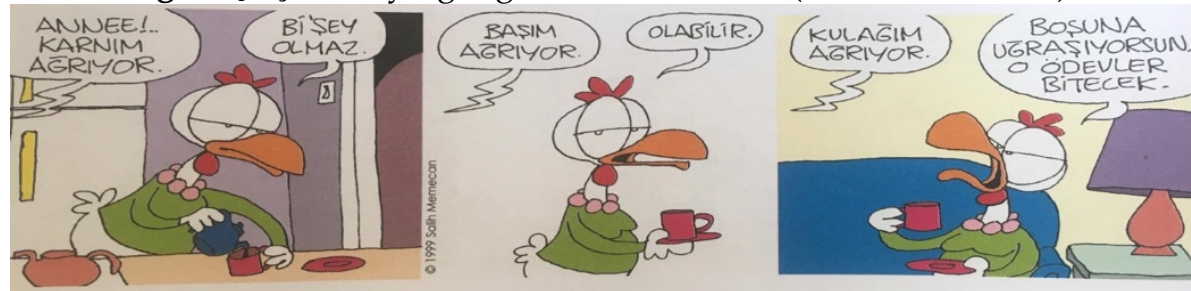

Fig. 5: Çıtçıt forcing Limon to do her homework (Sihirli Annem, 22).
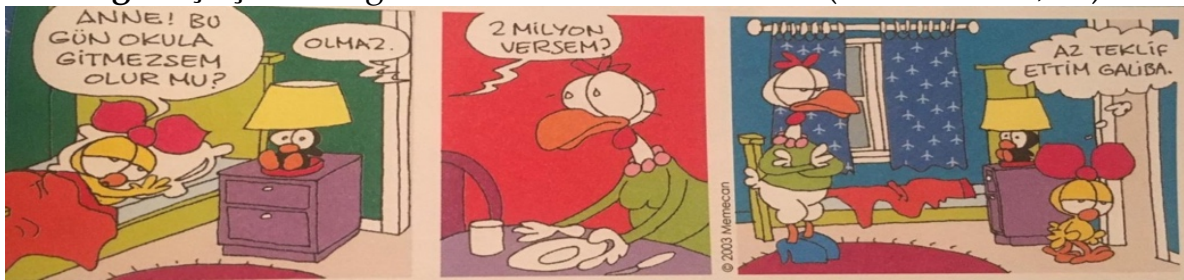

Fig. 6: Çıtçıt forcing Limon to go to school (İşte Benim Annem, 34).

In addition to Limon's eating routine and school stuff, Çıtçıt achieves to be the effective figure to discipline Limon about bedtime. In both Annem and Sihirli Annem, the reader comes across with Çıtçıt's instant struggle with Limon to convince her to go to sleep. Not surprisingly, the mother is again alone in bedtime struggle with Limon:

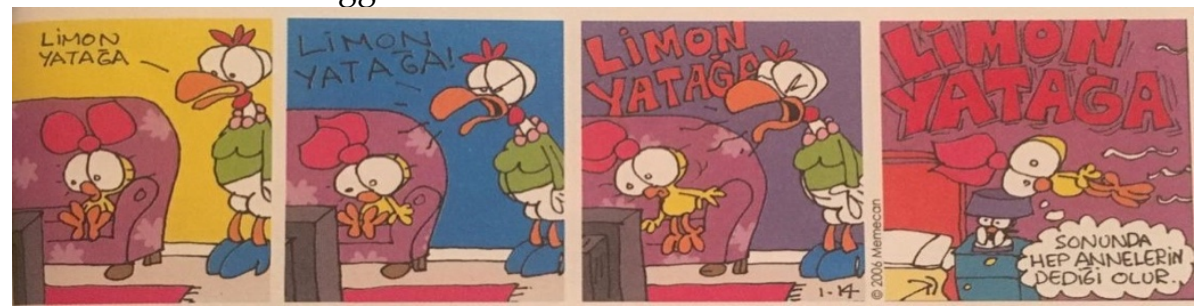

Fig. 7: Çıtçıt's struggle to persuade Limon to sleep (İşte Benim Annem, 38). 


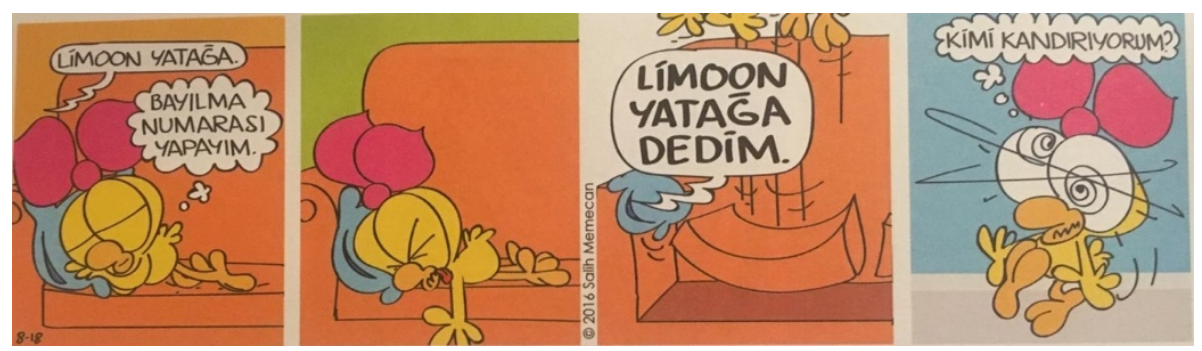

Fig. 8: Çıtçıt's growing impatience to put Limon to sleep (Annem, 62).

The division of labour between the mother and father in this family does not go any further than the model in traditional marriages. Besides taking the whole responsibility in raising their daughter Limon, the mother is the one who is also responsible for household chores, making Çıtçıt a servant rather than a member of the house. Handling with all the duties, she is like an assistant figure to make things go smoothly in and outside the house. While dealing with housework such as laundry, ironing, or cooking, she also endeavours to answer her husband's demands. On the other hand, Babişko does nothing about the housework as there is not a single panel that the reader sees him serving his wife. In almost every panel in Sihirli Annem, the reader can see how Çıtçıt makes herself miserable in order to catch up with household chores and is tired of serving her husband. And at times, without showing any discomfort or shame, the husband asks his wife to serve him coffee for his own pleasure especially when he reads the newspaper. On the other hand, though Çıtçıt seems uneasy with all these, she does not make enough complaint to make herself understood, which shows that she has internalized the traditional approach in the division of labour between couples. Veltman explains,

as an institution that sets up caregiving, homemaking, and housecleaning as a career for women, marriage not only relegates women to the immanence of maintaining home and family behind the scenes. It also affords husbands greater freedom for transcendent activities even if husbands spend their greater freedom in leisure or in activities of immanence rather than in pursuit of transcendence because it assigns women the responsibility of maintaining home and family. ${ }^{19}$ In accordance with Veltman's statement, there are quite a few instances in the comic series that the reader sees Çıtçıt enjoying herself. She is quite away from

\footnotetext{
${ }^{19}$ Andrea Veltman, "The Sisyphean Torture of Housework: Simone de Beauvoir and Inequitable Divisions of Domestic Work in Marriage," Hypatia 19, no. 3 (2004): 126, https://doi.org/10.1111/j.1527-2001.2004.tb01304.x.
} 
sparing time for herself and doing some reading or any other kind of a joyful activity as a fully devoted housewife.

As Veltman continues,

When a man has a wife to keep his home, care for his children, cook his meals and so forth, he himself becomes freed up for more meaningful activity at home or in the world [...] having a wife who ministers to the life process nevertheless enables husbands to unload the tedious varieties of housework onto a female Other and to increase their own autonomy. ${ }^{20}$

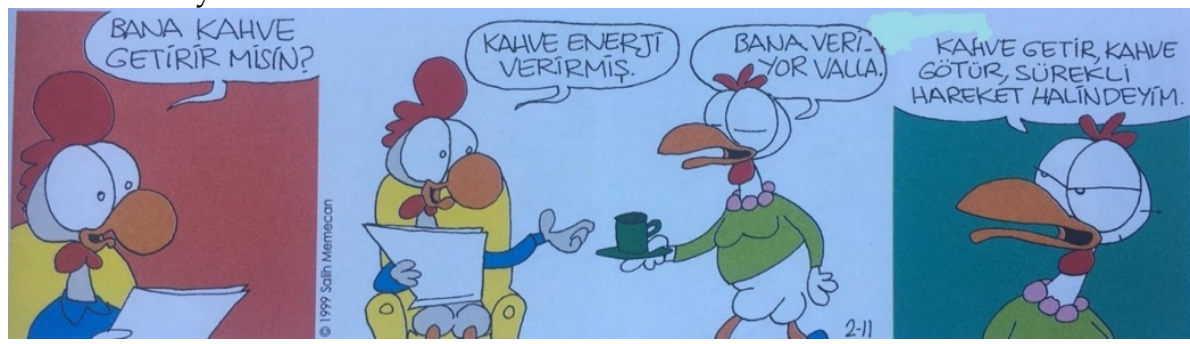

Fig. 9: Çıtçıt's complaint about serving her husband (Sihirli Annem, 15).

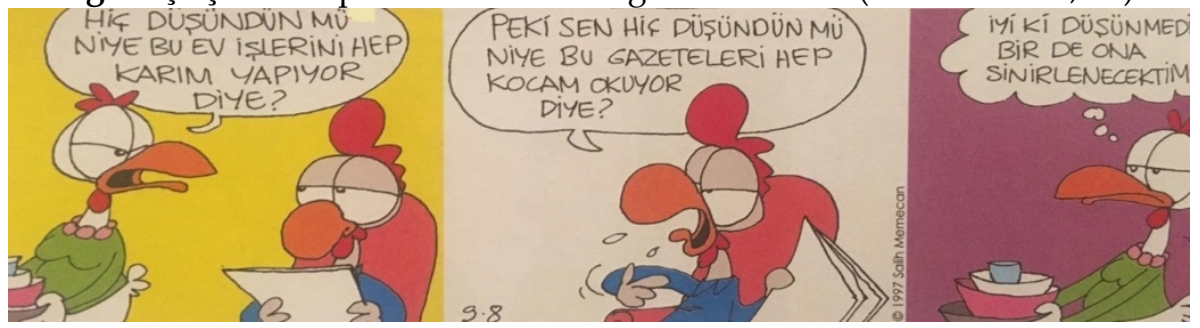

Fig. 10: Çıtçıt's complaint about housework (Sihirli Annem, 6).

Besides being sick of doing household chores and serving her husband all the time, Çıtçıt is also seen in a position that she is obliged to serve for her daughter. At the very beginning of the book Annem, in one of the conversations between Limon and Zeytin, Limon speaks of her mother as her private "robot" who cleans and tidies her room, helps her homework, plays with her, and does whatever she wants. It can be deduced from this conversation that in this house, the mother figure somehow turns into a kind of a mechanized figure whose only mission is to serve the other family members. Similarly, in another panel from the book Isste Benim Annem, Limon calls her mother as "server" when she asks for a glass of water from Çıtçıt:

${ }^{20}$ Ibid., 127. 


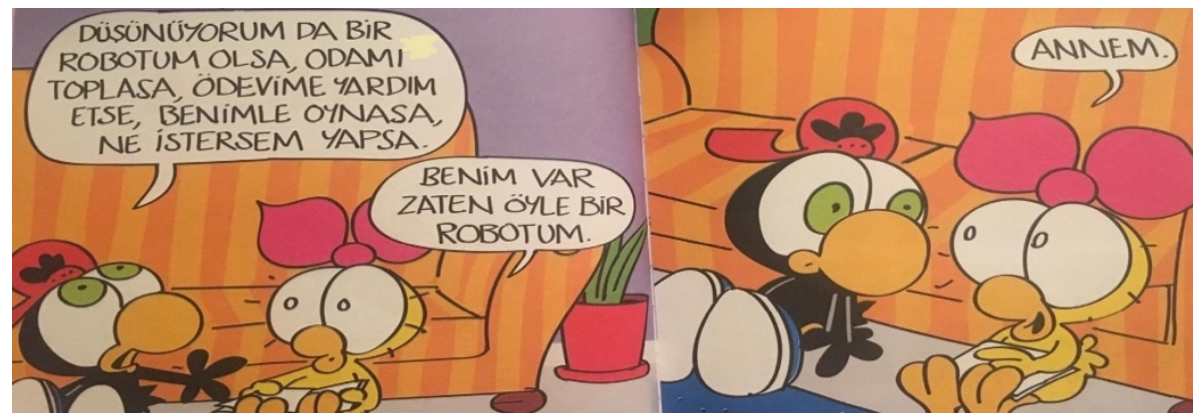

Fig. 11: Limon's mention her mother as a "robot" (Annem, 1).

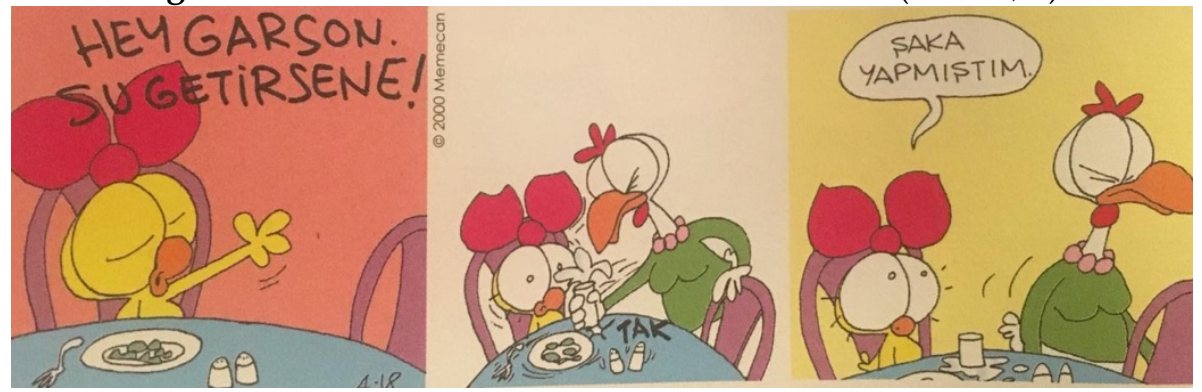

Fig. 12: Limon's calling her mother "server" (İşte Benim Annem, 7).

Other than the physical wariness due to being stuck in the house, Ç1tçıt is also mentally tired. There are few panels in which Çıtçıt is seen outside due to the burden of endless housework. She keeps herself so busy with the chores that she tends to get depressed just because she cannot think of anything to cook. She is shown to make the problem with the meal so gross that it even surpasses the thoughts and other problems in life when her husband asks her what makes her think so deeply. Portrayed as an individual devoted to working for others, she stays behind daily matters being unable to think that she indeed exists as an individual. In figure 12, it is obvious that it is not quite easy to plan the meal every day and as like the several other domestic matters it also "imprisons her in repetition and immanence, repeated from day to day in an identical form, without change and producing nothing new" ${ }^{21}$.

However, though she does her best to prepare food for her family, it seems that she is unable to satisfy them. In the panel when Çıtçıt declares she burned the food again, she also states "everybody takes it normally":

${ }^{21}$ Beauvoir, The Second Sex, 63. 

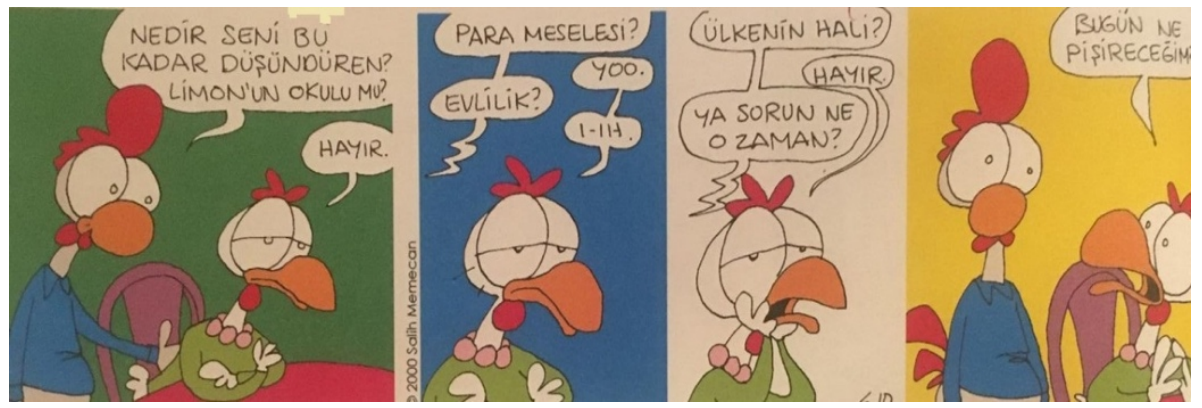

Fig. 13: Çıtçıt's mental entrapment in household chores (Sihirli Annem, 24).

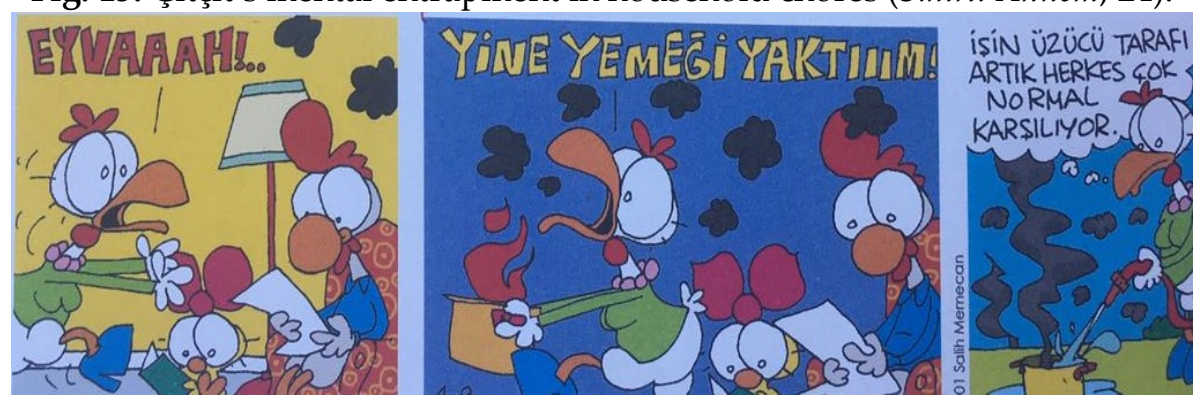

Fig. 14: The scene that Çıtçıt burned the food (Sihirli Annem, 32).

As a result of devoting herself to her husband and daughter, Çitçit, in the end, feels pitiable and gets depressed confessing that she is fed up with dealing with the same things every day. She finds her life meaningless; she looks to her husband to heal her soul and rise out of the depression. Unhappily, she again faces the fact that she is alone to overcome this process. She is hopeless and helpless just as she feels throughout her married life. When she says that she is in depression, her husband says he is in the living room, in a manner quite away from trying to understand and pay attention to what she says.

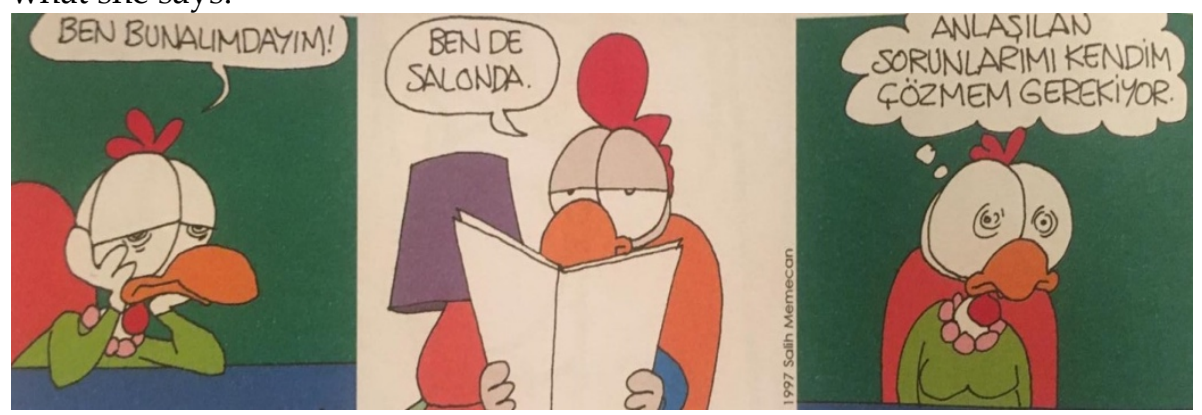

Fig. 15: Çıtçıt's depression (Sihirli Annem, 8). 


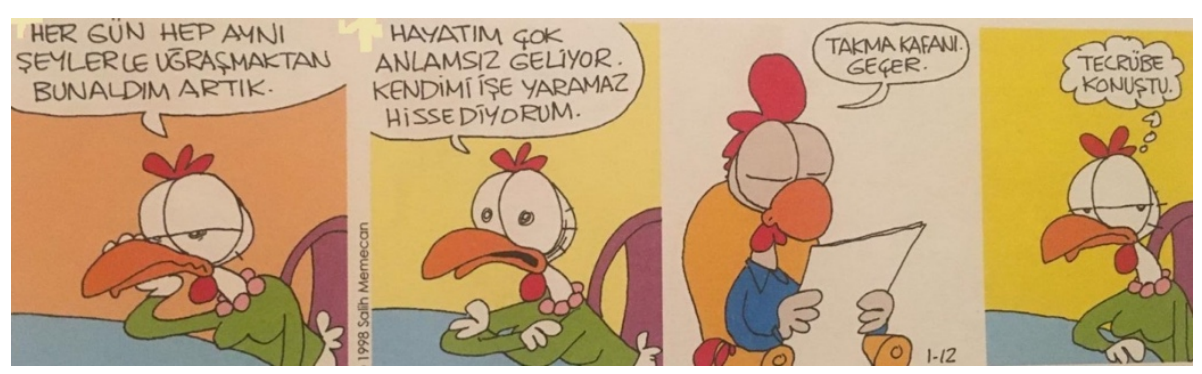

Fig. 16: Çıtçıt feels fatigued because of the meaningless life (Sihirli Annem, 9).

Throughout the selected panels, Çitçıt's life only consists of the monotonous repetition of the things. As her identity is stuck between a wife and mother, she is unable to do something for herself. As a result of this monotonous way of life, getting into a kind of depression becomes an inevitable ending for her.

\section{Conclusion}

In this paper, Salih Memecan's three comic strips from the series of Limon and Zeytin: Annem, İşte Benim Annem and Sihirli Annem have been studied from a feminist point of view. The issue of motherhood and gender roles in a conventional marriage have been examined and found out that Çıtçıt is represented as a mother figure who sacrifices herself for the sake of her family and thus being a housewife as a servant, while the father figure is the one who neither takes part in domestic work nor in parental issues. It has been concluded that the mother figure becomes like a full-time servant who always serves her husband and daughter and puts their demands before her own needs. As a self-absorbed father figure, Babişko subjugates his wife to cope with all the responsibilities in growing their daughter, Limon as well as household chores. He debars her from his support and seems indifferent towards her problem when Çıtçıt feels depressed and searches for a way to recover. Unlike an empowered mother figure described in the book Matricentric Feminism, Çıtçıt is seen as the one who is deprived of selfrealization and oppressed by motherhood and wifehood within a predominantly masculine society. Therefore, although it may seem that marriage, domestic work, childcare and motherhood are differing issues, they are all combined and melted under the constitution of marriage through special supervision of women. On account of the long-lined internalization of gender roles that frequently echo women's belonging to the domestic sphere and men's to the public and intellectual sphere, there are few efforts to separate and focus on the requirements of these notions as couples. The hard- 
to-erase scenes where mothers are seen doing several things at one time pose a great burden for woman, yet it opens and favours the loss of domestic load on men, who takes such an established misunderstanding for granted. Memecan's selected comics in this article are proper examples of the incarceration of the woman figure that contrastingly paves the way for a freer life for the husband and/or partner. 


\section{Bibliography}

Allen, Jeffner. "Motherhood: The Annihilation of Women." In Mothering: Essays in Feminist Theory, edited by Joyce Trebilcot, 315-330. Totowa, N. J. : Rowman \& Allanheld, 1984.

O'Reilly, Andrea. Matricentric Feminism: Theory, Activism, and Practice. Bradford, Ontario: Demeter Press, 2016.

Beauvoir, Simone De. The Second Sex. London: Jonathan Cape. 1953.

Diquinzio, Patrice. 'Exclusion and Essentialism in Feminist Theory: The Problem of Mothering'. Hypatia 8, no. 3 (1993): 1-20.

Gündüz, Zuhal Yeşilyurt. 'The Women's Movement in Turkey: From Tanzimat towards European Union Membership 1'. Perceptions: Journal of International Affairs 9, no. 3 (2004): 11534.

Hooks, Bell. Feminist Theory: From Margin to Center. Boston: South End Press, 2000.

Kaya, Senem Üstün. 'Angels or Demons: A Comparative Analysis of Motherhood Concept in World Literature'. Akademik Dil ve Edebiyat Dergisi 4, no. 4 (2020): 87287. https://doi.org/10.34083/akaded.755543.

Memecan, Salih. Annem. İstanbul: Mart Yayınları, 2017. İşte Benim Annem. İstanbul: Mart Yayınları, 2015. . Sihirli Annem. İstanbul: Mart Ajans Yayıncılık, 2016.

Neyer, Gerda, and Laura Bernardi. 'Feminist Perspectives on Motherhood and Reproduction'. Historical Social Research / Historische Sozialforschung 36, no. 2 (136) (2011): 162-76.

Rich, Adrienne. Of Woman Born. New York: Norton Publishing, 1986.

Russ, Joanna. How to Suppress Women's Writing. Austin, Texas: University of Texas Press, 1983.

Selçuk, Ayşe Bilge. 'Türkiye'de Ebeveynlik'. Cogito 81 (2015): 108- 200.

Takševa, Tatjana. 'Mother Love, Maternal Ambivalence, and the Possibility of Empowered Mothering'. Hypatia 32, no. 1 (2017): 152-68. https://doi.org/10.1111/hypa.12310.

Thompson, Mary. 'Third Wave Feminism and the Politics of Motherhood'. Genders 1, no. 2 (2016). https://www.colorado.edu/genders/2017/03/17/third-wave-feminism-and-politicsmotherhood.

Veltman, Andrea. 'The Sisyphean Torture of Housework: Simone de Beauvoir and Inequitable Divisions of Domestic Work in Marriage'. Hypatia 19, no. 3 (ed 2004): 12143. https://doi.org/10.1111/j.1527-2001.2004.tb01304.x. 